\title{
IIIT Panels at the 2016 ISNA Convention
}

The International Institute of Islamic Thought (IIIT) held a series of panels at ISNA's 41st annual convention in Chicago, IL, on September 3-4, 2016.

\section{The Fiqh of Citizenship}

Saturday's first speaker, Tariq Ramadan (professor of contemporary Islamic studies, Oxford University), presented fiqh al-muwätanah (citizenship) and contended that "we need to go back to the main meaning of fiqh, which is the deep understanding and not the legal framework. And before we get to the fiqh al-muwātanah (citizenship), we need to get to fahm (understanding) almuwätanah. ... The way we deal with citizenship is not the right way. In a secular society you don't have minority citizenship, you are a citizen or you are not. So in this sense you belong to a structural society with a legal framework - understanding that every citizen has the same rights and duties." Jasser Auda (Al-Shabtibi Chair of Maqasid Studies, International Peace College, South Africa; executive director, Maqasid Institute) linked the maqāșid alShari' 'ah to the rights of minorities in Muslim-majority countries, thereby stressing that we need to look at the rights of all people: "Why do we single out certain communities based on religious lines in a secular state? In a secular state you are not supposed to identify based on your religion; you identify based on your citizenship. Once you establish your citizenship you have all the rights. But Islamophobes with funny agendas like to put Muslims in this bracket." He also reiterated that we should be tolerant and coexist with others as well as adhere to our own principles and religion.

Abubaker Al-Shingieti (regional executive director, IIIT) moderated the session.

\section{Islam and Democracy: Roots and Realities}

Abdulaziz Sachedina (professor and IIIT Chair in Islamic Studies, George Mason University) presented his The Islamic Roots of Democratic Pluralism (2000), which critically analyzes Islamic teachings on pluralism, civil society, war and peace, violence, and other issues. He spoke about the compatibility of Islam and democracy, and what Islam truly says about democracy while looking at actual Qur' anic foundations. Sachedina tackled the most significant issues facing Muslims today: those dealing with reopening the doors of $i j t i h \bar{a} d$ 
in order to correct false interpretations, replace outdated laws, and formulate new doctrines: "What I am searching for is actual Qur'anic foundations, Islamic foundation, for democratic thinking, for pluralistic thinking ... the acceptance of human beings as human beings first; this is where we have a battleground in the Muslim world today." He praised IIIT for providing opportunities for such undertakings. Ebrahim Rasool (former ambassador of South Africa to the United States; currently Georgetown University's distinguished scholarin-residence) lauded IIIT for opening and allowing thinking in the ummah. He emphasized and reiterated Sachedina's point that what we need is not tolerance, but acceptance of one another in order to live in harmony. In order to coexist with others, he asserted, we must ask the ummah's mostly authoritarian regimes: "How can you put regulations over democracy, when all we know are dictatorships? ... We are asked to develop the limitations of freedom, the containments of democracy, but we don't have it in the first place. [We need to first] accept the value and the principles of [democracy], and then work out the mechanisms and the regulations around it."

Dalia Fahmy (assistant professor of political science, LIU Brooklyn) moderated the session.

\section{Maqāșsid al-Sharī‘ah as a Philosophy of Islamic Law: A Systems Approach}

This panel, which revolved around Jasser Auda's Maqasid al-Shari 'ah as a Philosophy of Islamic Law: A Systems Approach (2008), sought to address problems via the theory of maqāsid al-Sharī'ah (the purpose of Islamic law) and systems theory. Maqāssid is proposed as a philosophy and fundamental methodology for assessing and developing classic and current juridical theories. Systems theory is utilized to define a new method for analysis that relies on the system's features of cognition, wholeness, openness, hierarchy, multi-dimensionality, and purposefulness. Auda began by explaining that the "maqāșid al-Shari' 'ah are the maqāsid, or purpose or object, and the why of the Sharia." He argued that new philosophies and methodologies are needed, for we live in constantly "changing world," and that it is important to have a proper reform process. Tafsīr (interpretation of the Qur'an) is absolutely necessary; however, it is also a human undertaking and therefore subject to error. Ebrahim Rasool, who thanked Auda for revolutionizing maqāșid al-Sharī' ah and how we analyze it, tied this into his experiences and difficulties as a governor in post-Apartheid South Africa. He spoke about his experience of reading the book: "For me, that is when the philosophies of thinking met the exigencies of 
government." He also mentioned that the importance of adaptability while making sure to ask "Is this a valid form of thinking in Islam?...This discipline of maqāșid al-Sharī'ah teaches us to make nuances and distinction the instrument of our thinking."

Patricia Anton moderated the session.

\section{The Joint IIIT Distinguished Scholar Award and Dr. Jamal Barzinji Memorial Lecture}

The joint IIIT Distinguished Scholar Award \& Dr. Jamal Barzinji Memorial Lecture honored and recognized Tariq Ramadan for his outstanding achievements in the field of Islamic studies. This event was held in commemoration of Dr. Jamal's remarkable intellectual contributions to the Muslim world. A founding member of the IIIT Board of Trustees and former vice president of research and publications, he passed away late last year.

After Al-Shingieti opened the memorial lecture with welcoming remarks, he introduced Ramadan as "an original thinker and a scholar who contributed to address with moral courage a lot of the intellectual issues but with the same courage he addresses the actual challenges, political and social, that face our community."

Hisham Altalib (president, IIIT) presented him with the IIIT Distinguished Scholar Award, stating that it is "well-deserved for the right person." Ramadan replied: "I am humbled because this award to me [represents] a very long relationship between the family in the intellectual and spiritual [world] between the school of thought and IIIT, the people, the fathers of the projects which have been investing in intellectual production at the highest level, and thinking about excellence when it comes to producing knowledge and spreading knowledge."

Altalib, a longtime friend of Dr. Jamal, was then invited to reflect upon his 60-year friendship with Dr. Jamal, his work in Europe and America, and his many unforgettable contributions to the Muslim world. He shared an ayah, "Among the believers are those who have fulfilled their promise and passed away," confirming that the rest of the IIIT founders will pursue their commitment and that the legacy of those who have passed on will be continued.

A summary of Dr. Jamal's work includes forty years of progressive experience in the development and leadership of diverse organizations, academic institutions, and businesses. Al-Shingieti also spoke about Dr. Jamal's legacy. "Dr. Jamal Barzinji has always been not only a source of inspiration, but he's a disciplinarian also, intellectually and management wise he has been a mentor in the true sense of the world and we miss him dearly." Rasool asked how we 
could pay tribute to such an extraordinary person: "People like Dr. Jamal Barzinji were not just ordinary people who came here, but were regarded as pioneers of this contemporary age of Muslims in the West, particularly in the United States."

Keynote speaker Ramadan began his speech by sharing his appreciation of his parents' support: "The first book I got from my mother, who didn't know French so well, was a book of French poetry. It was a message, saying this is nice, this is beautiful. She felt it was beautiful without knowing the language." He thanked and appreciated his family for its ongoing love and support, allowing open spaces for discussions, and empowering him to study what he loved - philosophy and literature. "This is saying something from a family coming from Egypt in exile, acknowledging the fact that this is your culture. There is beauty in this."

He spoke about his book, The Quest for Meaning: Developing a Philosophy of Pluralism (2010), which he calls a philosophical journey written to "open up the universal dimension of what a human being is." Written from a perspective of no particular faith, it uncovers the profound truths that bind all human beings together: "When you talk about the quest for meaning, you are asking, what is my life?" According to him, the underlying idea is: "By definition, human beings are in need of something. We have questions. We need answers. And as long as we are not getting these answers, we are not getting peace." He remarked that since all spiritual traditions contain something, "do not make it an Islamic thing. While Islam is telling you it is a universal reality, we are narrowing and reducing Islam to - let us give our answers, and that they are the only answers."

He touched on his various experiences abroad, working with nonMuslims, and reading in order to learn and gain knowledge from them: "We are coming from different paths trying to find the common values. ... If you are respecting me, don't tell me you are accepting me. Accepting me is not respect, nor is it knowledge; [rather,] it is living together, it is peaceful coexistence. We don't need peaceful coexistence, and we don't only want living together. Living together is not enough. It's acting together, doing together, in the name of common values."

His book Radical Reform (2008) provides what could be the Islamic answer to these questions. "Of course we need to adapt, because the world is moving. But we need to adapt with a thought which is helping us to transform the world for the better, not in legal terms. But in fact we don't need only law, we need a philosophy of law." He then stated that "I want to reform the Muslim mind, not Islam." 
In closing, he asked: "What is our contribution in the concert of this civilization, [and] our contribution in all the big questions that we have today?" He contended that we need open discussions in which we can critically analyze the issues facing the ummah in open spaces, for this will help us find the right means to achieve our common goals.

\section{The Story of the Qur'an}

Sunday's first panel centered on Ingrid Mattson's (London and Windsor Community Chair in Islamic Studies, Huron University College, Western University, Canada; former ISNA president) The Story of Qur'an: Its History and Place in Muslim Life (2007). She examined the Qur'anic doctrines and detailed their significance to Muslim people and societies through individual stories. The book analyzed how the Qur' an influences personal relationships, popular culture, law, art and architecture, political movements, science, and literature and other major aspects of society. After making two important points - the need to include the stories of women and the Shi' as, to give the readers the full picture as well as the need for the Muslim American community's leadership and speakers to reflect its members' enormous diversity she stated that there needs to be more leaders and speakers to reflect its demographics. In closing, she reminded the audience of the importance of interpreting the Qur'an, as well as the historical context and the role of reason in interpretation, and that "there is always a human element to interpretation," which means that this undertaking is not as simple as it seems. Hadia Mubarak (assistant professor of religion, Davidson College), discussed this book and shared some of the stories therein to indicate how the narratives in the book highlight the importance of the revelation and the divine wisdom by using a wide scope of sources and from both oral and written evidence. She then opined that this was the first successful work to portray the Muslim historic account with the vigor of western scholarship, and asserted that Mattson brings unique attention to the role of women in Islamic tradition: "As she writes from the perspective of a Western academic who is also a committed believer as she knows in her preface, her writing is infused with a deep spirituality which moves those who read it, rather than being a dry academic text, her work successfully captures her spirituality that is evoked by the Qur'an to its readers."

\section{Higher Education in Northern America}

The fifth and last panel featured brief presentations from professors and directors of North American Islamic colleges on various issues facing Islamic 
higher education, as well as potential collaborations and bench-marking to further its progress. Ermin Sinanović (director of research and educational programs, IIIT) focused on IIIT's role in higher education and efforts to collaborate with secular institutions of higher learning and theological seminaries, as well as its own educational programs. Jihad Turk (founder and president, Bayan Claremont) discussed his personal story and experiences in the field of Islamic studies. He then introduced Bayan Claremont as a graduate school designed to educate the next generation of Muslim scholars and religious leaders in the United States. In closing, he announced that Bayan Claremont is trying to meet the needs of the Islamic community by adding two new degrees, as well as featuring an executive masters' format, to become more flexible and attract more students.

Shabana Mir (assistant professor of anthropology, American Islamic College (AIC); author of the award-winning Muslim American Women on Campus: Undergraduate Social Life and Identity (2104) concentrated on how to rejuvenate Islamic colleges via collaboration. She would like to see an AIC program that offers creatively engaged thinking with Islamic studies. Furthermore, she spoke about difficulties associated with becoming an accredited institution and about leaving a public university and teaching at an Islamic institution: "I was blown away by the amazing climate at this college, by the fact that not only could I speak to mostly Muslim students, and we could study gender though Islamic history, and you could raise all of the questions and it was okay.... it was better than doing this work in a mainstream classroom, there was no need for a balancing act." Feryal Salem (assistant professor of Islamic scriptures and law, the Macdonald Center for the Study of Islam and Christian-Muslim Relations), spoke about her experience with the joint IIIT and Hartford Seminary program. She focused on the importance of having ideas challenged and critically thinking, speaking about the Hartford Seminary program and how it was beneficial to be a part of a diverse group, liberal and conservative Muslims and Christians: "It is beneficially in many ways... when a person is on an academic level and they are in graduate school it is beneficial to be exposed to different ideas and to have your ideas challenged." She briefly spoke about her upbringing in Syria, which sparked her interest in the field of Islamic studies.

Hadeel Elaradi Master's Candidate, Department of Middle Eastern and Islamic Studies George Mason University, Fairfax, VA 